\title{
Effective treatment of locally advanced periocular basal cell carcinoma with oral hedgehog pathway inhibitor?
}

\author{
Xiaoyi Hou ${ }^{1} \cdot$ Alexander C. Rokohl ${ }^{1} \cdot$ Monika Ortmann ${ }^{2} \cdot$ Ludwig M. Heindl $^{1,3}$ (B) \\ Received: 29 April 2020 /Revised: 29 April 2020 / Accepted: 1 June 2020 / Published online: 9 June 2020 \\ (C) The Author(s) 2020
}

Keywords Basal cell carcinoma $\cdot$ Eyelid carcinoma $\cdot$ Eyelid $\cdot$ Hedgehog pathway inhibitor $\cdot$ Sonidegib

\section{Dear Editor,}

Basal cell carcinoma (BCC) is the most common malignant tumor in the periocular region $[1,2]$. The vast majority of periocular BCCs can be effectively treated by complete histopathology-controlled excision, the gold standard for BCC treatment [3]. However, in some cases, alternative approaches are required due to advanced stage of the BCC, reduced general condition of the patient prohibiting general anesthesia, unreasonable cosmetic changes after surgery, or multiple BCC lesions such as in Gorlin-Goltz-syndrome [4]. These alternative approaches include among others systemic therapy with immune checkpoint inhibitors such as sonidegib $[4,5]$.

Sonidegib (Odomzo®), an oral hedgehog pathway inhibitor (HPI), is indicated for the treatment of adults with locally advanced $\mathrm{BCC}$ (laBCC) that are not candidates for surgery or radiation therapy or adults with recurrent laBCC following surgery or radiation therapy $[6,7]$. Until today, there is no report of sonidegib for treating periocular laBCC, and evidence regarding optimal management of this condition is still limited. Hence, we demonstrate a case of a laBCC on the lower eyelid margin which was successfully treated with sonidegib.

A 73-year-old man with a 20-year history of multiple BCCs at his back, chest, nose, and ear presented with a morphea-like BCC of the left lower eyelid along with an

Ludwig M. Heindl

ludwig.heindl@uk-koeln.de

1 Department of Ophthalmology, Faculty of Medicine and University Hospital Cologne, University of Cologne, Cologne, Germany

2 Department of Pathology, Faculty of Medicine and University Hospital Cologne, University of Cologne, Cologne, Germany

3 Center for Integrated Oncology (CIO)

Aachen-Bonn-Cologne-Duesseldorf, Cologne, Germany ectropion (Fig. 1a). Local biopsy revealed histopathologically confirmed BCC (Fig. 1b). The patient refused any further surgical or radiotherapeutic interventions and preferred systemic treatment. After oral treatment with sonidegib (capsule $200 \mathrm{mg}$; Odomzo () once a day for 6 months, the lesions on the eyelid margin showed no significant clinical remission, and the lower eyelid ectropion persisted (Fig. 1c). Due to the suspicion of a persistent malignant process and in order to treat the ectropion, a full-thickness biopsy of the lower eyelid was performed. The histopathology revealed no manifestation of a BCC anymore but only nonspecific inflammation and slight parakeratosis (Fig. 1d).

Ninety percent of BCCs have a pathologic activation of the sonic hedgehog pathway; vismodegib is the first HPI been applicated in the treatment of periocular laBCC [8]. However, during treatment with vismodegib, new squamous cell carcinomas (SCC) of the skin were seen [8], and it is currently still unclear whether these SCCs were a side effect or a coincidence of BCC. Sonidegib (200 mg), the second hedgehog inhibitor approved, was successfully applied for use in patients with laBCC [6] based on the meaningful, durable tumor responses observed in the BCC outcomes with the BOLT study [9]. Nevertheless, there is no study investigating the effectiveness of sonidegib for treating periocular laBCC until now.

Our patient was the first case of a successful treatment of oral HPI for periocular laBCC. In our case, histopathologyconfirmed complete remission was achieved under therapy with $200 \mathrm{mg}$ sonidegib with only slight side effects, including muscle spasms and vomiting. A second malignancy did not occur after 6 months treatment with sonidegib. Hence, our report suggests that sonidegib seems to be an effective treatment option for periocular laBCCs without the side effect of secondary malignancies. However, long-term efficacy and complications have to be investigated in further studies with a larger population. 

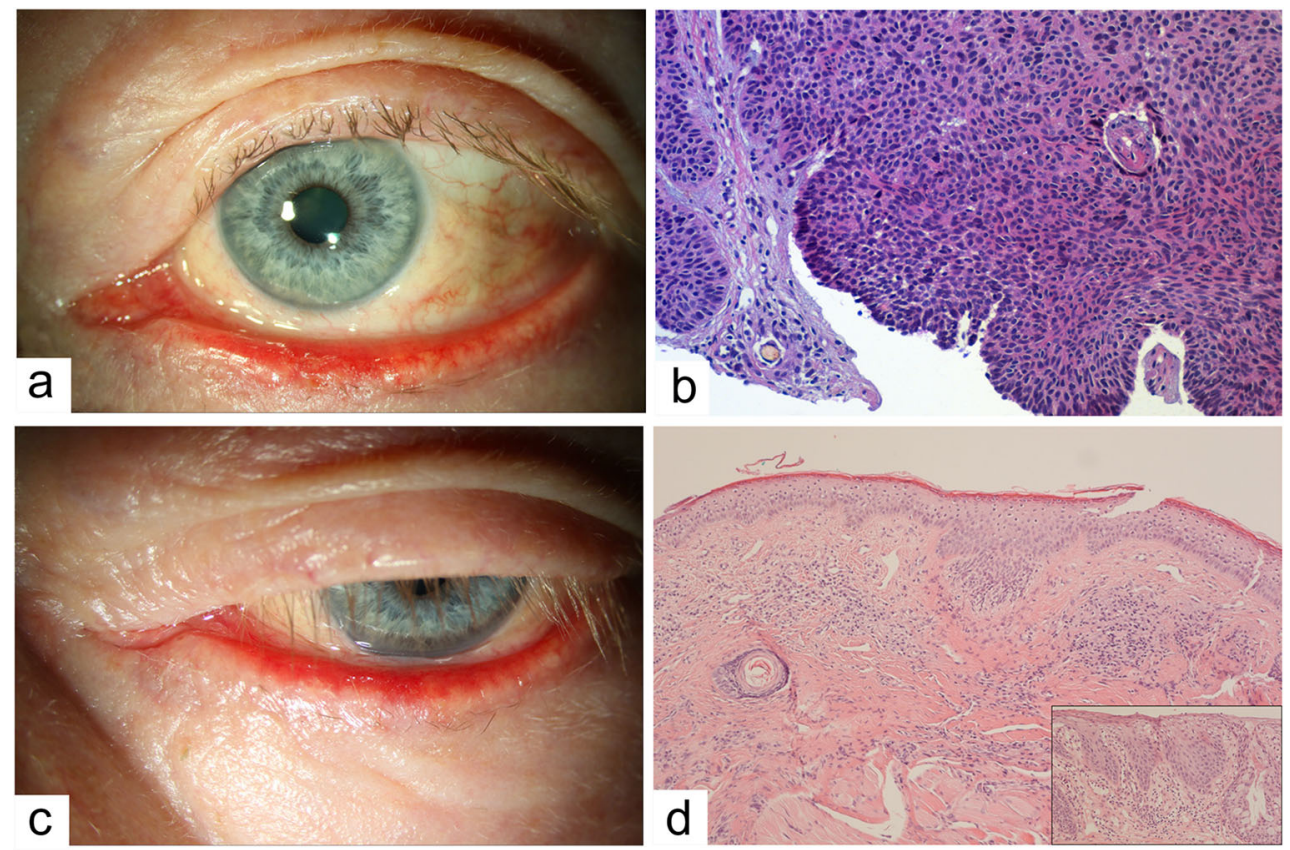

Fig. 1 Lower eyelid basal cell carcinoma (BCC) treated with sonidegib. a A 73-year-old man with a 20-year history of multiple BCCs at his back, chest, nose, and ear presented with marked blepharitis and ulcered lesion in the center of the lower eyelid margin with clinical suspicion of a morphea-type BCC. b Hematoxylin-eosin (HE) staining of the biopsy shows basaloid nests as well as typical gap formation between tumor cell nests and the surrounding stroma (arrow) (HE: $\times 10)$, compatible with

Acknowledgement We thank Stefan Kraft (Center for Dermatopathology Freiburg) for providing Figure $1 \mathrm{~b}$.

Authors' contributions: Xiaoyi Hou and Alexander C. Rokohl collected the data and were major contributors in writing the manuscript. Monika Ortmann helped to analyze the pathological data. Ludwig M. Heindl designed the project and revised the manuscript for important intellectual content. All authors approved the version to be published.

Funding Information Open Access funding provided by Projekt DEAL.

\section{Compliance with ethical standards}

Conflict of Interest The authors declare that they have no conflict of interest.

Ethics Approval All procedures performed in studies involving human participants were in accordance with the ethical standards of the institutional research committee and with the 1964 Helsinki Declaration and its later amendments or comparable ethical standards.

Patient Consent The patient has consented to the submission of the letter to the journal.

Open Access This article is licensed under a Creative Commons Attribution 4.0 International License, which permits use, sharing, adaptation, distribution and reproduction in any medium or format, as long as you give appropriate credit to the original author(s) and the source, provide a link to the Creative Commons licence, and indicate if changes were

BCC. c Following treatment with sonidegib for 6 months, there was marked persisting blepharitis and lower eyelid ectropion, suspicious for $\mathrm{BCC}$ recurrence. $\mathbf{d} \mathrm{HE}$ staining of the second full-thickness biopsy shows tiny foreign body granulomas and neutrophil adjacent to the deep epidermis $(H E: \times 10)$. Insert demonstrates the eyelid margin was edematically irritated without stronger layering disorder or cytological atypia, presenting with hypokeratosis $(\mathrm{HE}: \times 20$ ), ruling out $\mathrm{BCC}$ recurrence

made. The images or other third party material in this article are included in the article's Creative Commons licence, unless indicated otherwise in a credit line to the material. If material is not included in the article's Creative Commons licence and your intended use is not permitted by statutory regulation or exceeds the permitted use, you will need to obtain permission directly from the copyright holder. To view a copy of this licence, visit http://creativecommons.org/licenses/by/4.0/.

\section{References}

1. Rokohl AC, Löser H, Mor JM, Loreck N, Koch KR, Heindl LM (2020) Young male patient with unusual space-occupying lesion of the lower eyelid. Ophthalmologe 117:73-77. https://doi.org/10. 1007/s00347-019-00948-y

2. Lang BM, Balermpas P, Bauer A et al (2019) S2k guidelines for cutaneous basal cell carcinoma - part 2: treatment, prevention and follow-up. J Dtsch Dermatol Ges 17:214-230. https://doi.org/10. 1111/ddg. 13755

3. Kopecky A, Rokohl AC, Heindl LM (2018) Techniques for the reconstruction of the posterior eyelid lamella. Klin Monb1 Augenheilkd 235:1415-1428. https://doi.org/10.1055/a-0751-1069

4. Rokohl AC, Koch KR, Mor JM, Loreck N, Schlaak M, Mauch C, Bechrakis NE, Mohi A, Kakkassery V, Heindl LM (2020) Personalized medicine in the treatment of periocular tumors : targeted treatment and use of immune checkpoint inhibitors. Ophthalmologe Epub ahead of print. https://doi.org/10.1007/ s00347-019-01034-z 
5. Kakkassery V, Emmert S, Adamietz IA, Kovács G, Jünemann AM, Otte C, Zimbelmann M, Brosig A, Grisanti S, Heindl LM (2020) Alternative treatment options for periorbital basal cell carcinoma. Ophthalmologe 117:113-123. https://doi.org/10.1007/s00347-01901021-4

6. Mathis J, Doerr T, Lin E, Ibrahim SF (2019) Oral hedgehog pathway inhibition as a means for ocular salvage in locally advanced intraorbital basal cell carcinoma. Dermatol Surg 45:17-25. https:// doi.org/10.1097/DSS.0000000000001640

7. Kakkassery V, Loeffler KU, Sand M, Koch KR, Lentzsch AM, Nick AC, Adamietz IA, Heindl LM (2017) Current diagnostics and therapy recommendations for ocular basal cell carcinoma. Ophthalmologe 114:224-236. https://doi.org/10.1007/s00347-0160370-1
8. Ally MS, Aasi S, Wysong A, Teng C, Anderson E, Bailey-Healy I, Oro A, Kim J, Chang AL, Tang JY (2014) An investigator-initiated open-label clinical trial of vismodegib as a neoadjuvant to surgery for high-risk basal cell carcinoma. J Am Acad Dermatol 71:904-911. https://doi.org/10.1016/j.jaad.2014.05.020

9. Dummer R, Guminski A, Gutzmer R et al (2016) The 12-month analysis from basal cell carcinoma outcomes with LDE225 treatment (BOLT): a phase II, randomized, double-blind study of sonidegib in patients with advanced basal cell carcinoma. J Am Acad Dermatol 75:113-125. https://doi.org/10.1016/j.jaad.2016.02.1226

Publisher's note Springer Nature remains neutral with regard to jurisdictional claims in published maps and institutional affiliations. 